NASA TECHNICAL NOTE

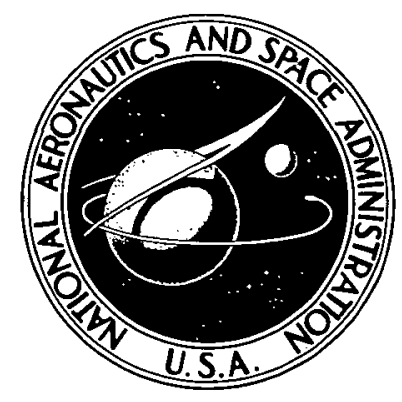

$$
N 73-21454
$$

NASA TN D-7255

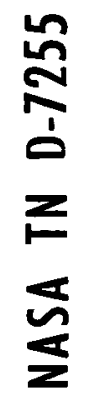

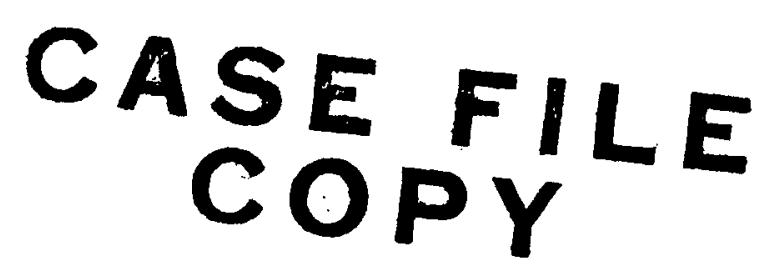

FORMATION AND BREAKDOWN

OF A PROTECTIVE LAYER

OF CHROMIUM SESQUIOXIDE

ON L-605 ALLOY AT $1100^{\circ} \mathrm{C}$

by Carl E. Lowell and Daniel L. Deadmore

Lewis Research Center

Cleveland, Obio 44135

NATIONAL aERONAUtics AND SPACE ADMINISTRATION - WASHINGTON, D. C. • APRIL 1973 


\begin{tabular}{|c|c|c|c|}
\hline $\begin{array}{l}\text { 1. Report No. } \\
\text { NASA TN D-7255 }\end{array}$ & 2. Government Accession No. & \multicolumn{2}{|c|}{ 3. Recipient's Catalog No. } \\
\hline \multirow{2}{*}{\multicolumn{2}{|c|}{$\begin{array}{l}\text { 4. Title and Subtitle } \\
\text { FORMATION AND BREAKDOWN OF A PROTECTIVE LA YER OF } \\
\text { CHROMIUM SESQUIOXIDE ON L-605 ALLOY AT } 1100^{\circ} \mathrm{C}\end{array}$}} & \multicolumn{2}{|l|}{$\begin{array}{l}\text { 5. Report Date } \\
\text { April } 1973\end{array}$} \\
\hline & & \multicolumn{2}{|c|}{ 6. Performing Organization Code } \\
\hline \multicolumn{2}{|c|}{$\begin{array}{l}\text { 7. Author(s) } \\
\text { Carl E. Lowell and Daniel L. Deadmore }\end{array}$} & \multicolumn{2}{|c|}{$\begin{array}{l}\text { 8. Performing Organization Report No. } \\
\text { E-7322 }\end{array}$} \\
\hline \multirow{3}{*}{\multicolumn{2}{|c|}{$\begin{array}{l}\text { 9. Performing Organization Name and Address } \\
\text { Lewis Research Center } \\
\text { National Aeronautics and Space Administration } \\
\text { Cleveland, Ohio } 44135\end{array}$}} & \multicolumn{2}{|l|}{$\begin{array}{l}\text { 10. Work Unit No. } \\
501-01\end{array}$} \\
\hline & & \multicolumn{2}{|c|}{ 11. Contract or Grant No. } \\
\hline & & \multirow{2}{*}{\multicolumn{2}{|c|}{$\begin{array}{l}\text { 13. Type of Report and Period Covered } \\
\text { Technical Note }\end{array}$}} \\
\hline \multirow{2}{*}{\multicolumn{2}{|c|}{$\begin{array}{l}\text { 12. Sponsoring Agency Name and Address } \\
\text { National Aeronautics and Space Administration } \\
\text { Washington, D.C. } 20546\end{array}$}} & & \\
\hline & & \multicolumn{2}{|c|}{ 14. Sponsoring Agency Code } \\
\hline \multicolumn{4}{|l|}{ 15. Supplementary Notes } \\
\hline \multicolumn{4}{|c|}{$\begin{array}{l}\text { 16. Abstract } \\
\text { The formation and breakdown of a protective layer of } \mathrm{Cr}_{2} \mathrm{O}_{3} \text { on the cobalt-base alloy L-605 } \\
\text { during oxidation at } 1100^{\circ} \mathrm{C} \text { was evaluated. Deformed surface layers, pressure, and moisture } \\
\text { were variables. Increasing surface deformation, decreasing pressure, and decreasing mois- } \\
\text { ture increased time to breakdown. A model was deduced. The breakdown of the } \mathrm{Cr}_{2} \mathrm{O}_{3} \text { layer } \\
\text { was caused by a combination of growth stresses and volatilization. Breakdown exposed a } \\
\text { chromium-depleted alloy to air, resulting in very rapid oxidation, which continued until con- } \\
\text { sumption of the depletion zone was complete. }\end{array}$} \\
\hline $\begin{array}{l}\text { 17. Key Words (Suggested by Author(s)) } \\
\text { Oxidation } \\
\text { Superalloy } \\
\text { Cobalt } \\
\text { Volatility }\end{array}$ & \multicolumn{3}{|c|}{$\begin{array}{l}\text { 18. Distribution Statement } \\
\text { Unclassified - unlimited }\end{array}$} \\
\hline $\begin{array}{l}\text { 19. Security Classif. (of this report) } \\
\text { Unclassified }\end{array}$ & $\begin{array}{l}\text { 20. Security Classif. (of this page) } \\
\text { Unclassified }\end{array}$ & $\begin{array}{c}\text { 21. No. of Pages } \\
17\end{array}$ & $\begin{array}{l}\text { 22. Price" } \\
\$ 3.00\end{array}$ \\
\hline
\end{tabular}

${ }^{*}$ For sale by the National Technical Information Service, Springfield, Virginia 22151 


\title{
FORMATION AND BREAKDOWN OF A PROTECTIVE LAYYER OF CHROMIUM SESQUIOXIDE ON L-605 ALLOY AT $1100^{\circ} \mathrm{C}$
}

\author{
by Carl E. Lowell and Daniel L. Deadmore
}

Lewis Research Center

\section{SUMMARY}

The formation and breakdown of a protective layer of $\mathrm{Cr}_{2} \mathrm{O}_{3}$ on L-605 during oxidation at $1100^{\circ} \mathrm{C}$ was investigated. The effects of surface deformation, pressure, and water vapor on the breakdown time were evaluated. It was found that increasing surface deformation increased the time to breakdown. Decreasing pressure below 1 atmosphere, to $1 \times 15^{-3}$ torr increased the time until breakdown, as did decreasing water content from 25000 to 2.5 parts per million.

By metallographic and microprobe examinations of samples during breakdown, a model was deduced. Surface deformation promotes $\mathrm{Cr}_{2} \mathrm{O}_{3}$ formation, while increasing pressure and moisture increases the volatility of $\mathrm{Cr}_{2} \mathrm{O}_{3}$. Thus, the $\mathrm{Cr}_{2} \mathrm{O}_{3}$ grows for a time which is determined by these three factors. At the end of this time the growth stresses cause the oxide to crack, exposing a chromium-depleted metal surface to the oxidizing gas. The resultant rapid oxidation of this surface lifts the remaining $\mathrm{Cr}_{2} \mathrm{O}_{3}$, exposing more depleted metal. When the depletion zone is consumed and a very thick oxide has formed, the rate of oxidation slows and no further disruption is noted.

\section{INTRODUCTION}

The cobalt-base superalloy L-605 is used in air-breathing engines. Its oxidation behavior has been reviewed extensively by Wlodek (ref. 1) and Wolf and Sandrock (ref. 2). Wlodek found that cobalt chromite $\left(\mathrm{CoCr}_{2} \mathrm{O}_{4}\right)$ was the controlling oxide formed. In the temperature range of $1700^{\circ}$ to $2200^{\circ} \mathrm{F}\left(925^{\circ}\right.$ to $1204^{\circ} \mathrm{C}$ ), he found that the oxidation was characterized by nearly parabolic growth of the scale.

Wolf and Sandrock attempted to determine the effect of silicon (Si) content on the oxidation of L-605. They found that some heats of the alloy with low Si or manganese $(\mathrm{Mn})$ contents exhibited excessive oxidation, which was typified by what they termed 
"an anomalous weight increment" at $1100^{\circ} \mathrm{C}$. By this they meant that these alloys started to oxidize parabolically and then at some time less than 20 hours the rate increased abruptly by more than 100 times. After a period of less than an hour, the rate once again slowed to approximately the initial rate. The authors were able to reproduce the effect only qualitatively. Identical compositions would differ in the time of the increase by a factor of 10 . The primary explanation given for this effect was that, during the first stages of oxidation, chromium sesquioxide $\left(\mathrm{Cr}_{2} \mathrm{O}_{3}\right)$ formed under stress caused by the mechanism of growth. At some point these stresses were relieved by failure of the metal, exposing unoxidized metal with a surface area very much larger than the original area to an oxidizing atmosphere and resulting in the observed rapid oxidation. They stated that once the new areas were oxidized the rate again dropped. As pointed out by Wolf and Sandrock, this phenomenon appears to be quite general and has been found in other cobalt-base superalloys (e.g., WI-52 (ref. 3)) and in simple binaries (e.g., iron-chromium (Fe-Cr) (ref. 4), nickel-chromium (Ni-Cr) (ref. 5), and cobaltchromium (ref. 6)). However, these other investigations associated the rapid weight change with a breakdown of the $\mathrm{Cr}_{2} \mathrm{O}_{3}$ scale, which allowed a chromium-depleted alloy to oxidize rapidly (ref. 7). In all cases, the time of breakdown was erratic, making this alloy difficult to study.

Work on WI-52, also a cobalt-base superalloy with similar chromium and tungsten (W) contents, indicated that the rapid oxidation effect might be somewhat dependent on surface preparation (ref. 3). This work indicated that some initial surface deformation was needed to form a single-phase layer of $\mathrm{Cr}_{2} \mathrm{O}_{3}$. Reference 8 indicates that this probably derived from the formation of small grains with attendant enhanced $\mathrm{Cr}$ diffusion along the grain boundaries. Without the stress, CoO and $\mathrm{Cr}_{2} \mathrm{O}_{3}$ formed and immediately reacted to form $\mathrm{CoCr}_{2} \mathrm{O}_{4}$; thus, there was no stressed $\mathrm{Cr}_{2} \mathrm{O}_{3}$ to break down.

The purpose of the current work was to determine which, if either, proposed mechanism for the "anomalous weight increment" is the correct one, in hopes of controlling the effect. To do this it was first necessary to control the variables causing the apparently erratic behavior so that its occurrences could be predicted and the phenomenon studied while in progress.

This work inv' red the isothermal oxidation of L-605, with the composition found by Wolf and Sandrock to be most prone to the "anomalous weight increment. " The oxidation temperature was $1100^{\circ} \mathrm{C}$ for times to 100 hours. The surface preparation of the samples was varied from a metallographic polish to abrasion with 120-grit paper. The moisture content of the air was controlled, and the pressure was varied from $1 \times 10^{-3}$ to 760 torr although the bulk of the work was done at near-atmospheric pressure.

In addition to gathering weight change data, the samples were evaluated by $\mathrm{X}$-ray diffraction, metallography, and electron microprobe. A model for the mechanism of this phenomenon is presented. 


\section{EXPERIMENTAL PROCEDURE}

\section{Material and Preparation}

All samples were cut from a sheet of hot-rolled and mill-annealed $\left(1230^{\circ} \mathrm{C}\right.$ solution treated, rapid air cooled) material about 1 millimeter thick. This sheet is from heat 8 of reference 2, which was found to have a pronounced tendency for the "anomalous weight increment." The composition of this heat is given in table I. Samples were cut from the sheet into 1.9-centimeter by 2.2-centimeter pieces. A variety of surface roughnesses and surface deformations were introduced by grinding and polishing, as shown in table II. Surface roughness was measured with a profilometer, while surface deformations were ranked by standard X-ray diffraction line-broadening techniques. Finally, the samples were ultrasonically cleaned in trichloroethylene, followed by a methanol rinse.

\section{Oxidation}

Two oxidation balances were used. While these balances had different operating characteristics, oxidation under similar atmospheres in each gave similar results. They are shown in figures 1 (a) and (b). Both balances have automatic recording to a precision of \pm 0.2 milligram. There are two differences between them: the method of starting the heating cycle and the atmosphere control. The initiation of oxidation for the balance in figure 1 (a) is accomplished by raising the furnace; and there is no atmosphere control, the sample being fully exposed when the furnace is lowered. The balance in figure 1(b) requires the sample to be lowered and/or gas admitted at the start of the run. The atmosphere can be closely controlled, and pressures less than $10^{-5}$ torr can be maintained. The main advantage of the former system is that the sample can be withdrawn within a few minutes of the termination of the run. The main advantage of the latter is the control over the oxidizing atmosphere. Temperature control in both was better than $\pm 5^{\circ} \mathrm{C}$.

Runs made in the apparatus in figure 1 (a) were started by raising the furnace. Most runs were carried on with no further changes. Some runs were made in which moist air was introduced at either the start of the test or at a predetermined point during the test. Samples were cooled by lowering the furnace. Because of the tendency for spallation of the oxide, some samples were quickly (less than $30 \mathrm{sec}$ ) transferred to a mold, where a low-melting-point liquid metal was poured over the sample. This step helped retain the scale for metallographic examination. When samples were not encased in metal, they were allowed to cool with a beaker surrounding them to collect the spall for analysis. 
Runs in the apparatus of figure $1(\mathrm{~b})$ were begun with the sample raised from the hot zone and the system evacuated. The desired gas was then allowed to flow into the system. After the pressure and temperature had reached equilibrium, the sample was lowered into the hot zone and the run begun. At the end of the run, the sample was retracted, the system opened, and the sample removed.

\section{Analysis}

Where possible, in-situ oxide and spalled oxide were examined by X-ray diffraction. Samples mounted in metal were sectioned and examined metallographically. Selected samples were examined in the electron microprobe with both raster scan and line scan techniques.

\section{RESULTS AND DISCUSSION}

\section{Weight Change}

A typical plot of isothermal weight change against exposure time is shown in figure 2. It has three distinct portions. First, there is a region of slow, parabolic growth with a low rate constant $\mathrm{K}_{\mathrm{p}}$. This region is abruptly terminated by an oxidation rate increase of over 100 times. This rate then gradually decreases to a rate close to the initial rate, 0.20 to $0.30 \mathrm{mg}^{2} \mathrm{~cm}^{-4} \mathrm{hr}^{-1}$. Phalnikar, Evans, and Baldwin (ref. 9) have shown $K_{p}$ values of approximately $0.20 \mathrm{mg}^{2} \mathrm{~cm}^{-4} \mathrm{hr}^{-1}$ in the cobalt-chromium system at $1100^{\circ} \mathrm{C}$ for compositions containing about 22-weight-percent chromium and $\mathrm{K}_{\mathrm{p}}$ values of $50 \mathrm{mg}^{2} \mathrm{~cm}^{-4} \mathrm{hr}^{-1}$ at about 17 -weight-percent chromium.

Although the moisture content of the oxidizing medium was not controlled, it is felt that the data of reference 9 are reasonably valid in showing the kind of $K_{p}$ ranges in this system. The major point is that for relatively small compositional changes (5 to 10 percent), the value of $\mathrm{K}_{\mathrm{p}}$ can vary over several orders of magnitude.

A characteristic, easy-to-measure parameter of curves such as figure 2 is the point at which the sudden increase begins. This time is, in effect, the life of the protective $\mathrm{Cr}_{2} \mathrm{O}_{3}$ layer. It is used in this report to show the effects of water vapor, surface deformation, and pressure. Figure 3 is a plot of the effect of both water vapor and prior surface deformation (as indicated by $\mathrm{X}$-ray line broadening) on the lifetime of the $\mathrm{Cr}_{2} \mathrm{O}_{3}$ layer. The curve for tests run at 2.5 parts per million (dewpoint $=-70^{\circ} \mathrm{C}$ ) $\mathrm{H}_{2} \mathrm{O}$ indicates a very strong function of $\mathrm{Cr}_{2} \mathrm{O}_{3}$ layer life on surface deformation (the lifetimes vary from less than $1 \mathrm{hr}$ to about $15 \mathrm{hrs}$ ). This indicates that increasing surface de- 
formation promotes the tendency for $\mathrm{Cr}_{2} \mathrm{O}_{3}$ formation, perhaps by increased diffusion of chromium along the increased grain boundaries of the fine grains formed during abrasion. Note that if the data were plotted against surface roughness (see table II), the ground sample would fall well off the curve. Thus, deformation, not roughness, is the important variable.

As the moisture content was raised to 8000 parts per million (dewpoint $=0^{\circ} \mathrm{C}$ ), the lifetimes were cut by $1 / 2$ to $1 / 3$. A further increase to 25000 parts per million (dewpoint $=25^{\circ} \mathrm{C}$ ) reduced the times to less than 1 hour. This phenomenon is associated with the loss of $\mathrm{Cr}_{2} \mathrm{O}_{3}$ as vapor by a reaction with $\mathrm{H}_{2} \mathrm{O}$ (see ref. 10). It presents a problem in data interpretation to the oxidation investigator who does not control the moisture content of the atmosphere during oxidation of $\mathrm{Cr}_{2} \mathrm{O}_{3}$-scale-forming alloys. However, it also offered a tool for use in the present investigation (see the following section, Metallography).

Kohl and Stearns (ref. 10) have also shown the strong effect of oxygen pressure on the loss of $\mathrm{CrO}_{3}$ vapor from $\mathrm{Cr}_{2} \mathrm{O}_{3}$. In this case the loss increases with $\mathrm{O}_{2}$ pressure as $\mathrm{CrO}_{3}$ formation increases. Thus, one would expect the $\mathrm{Cr}_{2} \mathrm{O}_{3}$ layer to last longer at low pressures. This is indeed the case, as shown in figure 4.

Diffraction, metallography, and microprobe X-ray diffraction confirmed the data of Wolf and Sandrock (ref. 2). $\mathrm{Cr}_{2} \mathrm{O}_{3}$ was the only oxide before the rapid increase in rate, while $\mathrm{CoO}, \mathrm{CoCr}_{2} \mathrm{O}_{4}, \mathrm{CoWO}_{4}$, and $\mathrm{Cr}_{2} \mathrm{O}_{3}$ were present afterward.

Metallography

As indicated in the preceding section, Weight Change, the water vapor effect was used to investigate the breakdown of the $\mathrm{Cr}_{2} \mathrm{O}_{3}$ layer. Samples with sufficient prior surface deformation to achieve long lives were initially oxidized in dry air. Then, at the desired moment, air saturated with water at $25^{\circ} \mathrm{C}$ was introduced. Within a few minutes, breakdown of the $\mathrm{Cr}_{2} \mathrm{O}_{3}$ layer began. This allowed samples to be removed and mounted just before, during, or after the breakdown.

The results of this work are illustrated in figures 5 to 8 . Figure $5(a)$ is the microstructure prior to breakdown. It shows the poorly adherent, blistered $\mathrm{Cr}_{2} \mathrm{O}_{3}$ seen by Wolf and Sandrock on L-605 (ref. 2) and by Caplan, Harvey, and Cohen on chromium (ref. 11). The microprobe trace of this sample (fig. 6) clearly shows the $\mathrm{Cr}_{2} \mathrm{O}_{3}$ layer and also indicates extreme chromium depletion in the metal beneath, with corresponding enrichment of cobalt and tungsten. Note that this depletion-zone composition appears low enough in chromium to produce a very high $\mathrm{K}_{\mathrm{p}}$ (up to $600 \mathrm{mg}^{2} \mathrm{~cm}^{-4} \mathrm{hr}^{-1}$ from ref. 11) upon oxidation. 
During the first stages of breakdown (fig. $5(\mathrm{~b})$ ), CoO is seen pushing up the $\mathrm{Cr}_{2} \mathrm{O}_{3}$. Note the thinner portions of $\mathrm{Cr}_{2} \mathrm{O}_{3}$ at the top of the blister. At the metal-oxide interface, rapid growth of $\mathrm{CoO}, \mathrm{CoCr}_{2} \mathrm{O}_{4}$, and $\mathrm{CoWO}_{4}$ occurs. The microprobe results help confirm this view (fig. 7).

Figures $5(\mathrm{c})$ and 8 show the sample in the third stage of $\mathrm{Cr}_{2} \mathrm{O}_{3}$ scale breakdown. $\mathrm{CoO}$ has grown completely around the $\mathrm{Cr}_{2} \mathrm{O}_{3}$, reacted with it, and formed $\mathrm{CoCr}_{2} \mathrm{O}_{4}$. As noted by Wolf and Sandrock (ref. 2) the shape of the original $\mathrm{Cr}_{2} \mathrm{O}_{3}$ is retained by the $\mathrm{CoCr}_{2} \mathrm{O}_{4}$. Also, as shown in figure 5(b) the nodes of the blisters are very thin. Figure 8 shows a very shallow chromium depletion zone beneath the scale.

\section{Oxidation Model}

Figure 9 represents a proposed model for the formation and breakdown of $\mathrm{Cr}_{2} \mathrm{O}_{3}$ on L-605. It is believed that the model has some general validity for most systems where this phenomenon has been observed.

The first step (fig. 9(a)) is the initial growth of $\mathrm{Cr}_{2} \mathrm{O}_{3}$ with its corresponding compressive stresses. As the stresses build, the oxide blisters begin to form and pull the oxide away from the metal in some spots (fig. 9(b)). The oxide grows by diffusion and diminishes by the reaction of $\mathrm{Cr}_{2} \mathrm{O}_{3}$ with $\mathrm{O}_{2}$ to form $\mathrm{CrO}_{3}$ vapor or with $\mathrm{H}_{2} \mathrm{O}$ to form $\mathrm{CrO}_{2}(\mathrm{OH})$. At points where the oxide is not in contact with the metal it is thinner (fig. $9(\mathrm{c})$ ) because the chromium would have to be vapor transported across the void, which must be a slower step. Next, the oxide cracks at these thin points either because the stress exceeds the load capabilities of the thin cross section or, less likely, because the vapor loss proceeds to open a hole. In either case, oxide cracking exposes chromium-depleted alloy to the oxidizing environment. CoO forms rapidly beneath the $\mathrm{Cr}_{2} \mathrm{O}_{3}$, lifting the loosely adhering oxide and allowing more depleted metal to be exposed (figs. 9(d) and (e)). Finally, the $\mathrm{CoO}$ envelopes the $\mathrm{Cr}_{2} \mathrm{O}_{3}$ layer, and with the thickening of the total layer and the consumption of the depleted metal the reaction slows down. The magnitude of the abrupt increase is somewhat proportional to the extent of the depleted zone at breakdown and is therefore related to the life of the initial $\mathrm{Cr}_{2} \mathrm{O}_{3}$ scale layer.

In cases where $\mathrm{Cr}_{2} \mathrm{O}_{3}$ is not allowed to form because of either high water content at the start of oxidation or insufficient stress, CoO forms from the start. This eliminates the breakdown phenomenon but at the expense of a much higher initial oxidation rate.

\section{SUMMARY OF RESULTS}

This work deals with the formation and breakdown of a protective layer of $\mathrm{Cr}_{2} \mathrm{O}_{3}$ on 
L-605 at $1100^{\circ} \mathrm{C}$. The material was oxidized for times up to 100 hours in air at pressures from $10^{-3}$.to 760 torr with water vapor contents from 2.5 to 25000 parts per million. The $\mathrm{Cr}_{2} \mathrm{O}_{3}$ layer formation and breakdown sequence was evaluated by weight change, X-ray diffraction, metallography, and electron microprobe. The major findings were as follows:

1. A protective layer consisting only of $\mathrm{Cr}_{2} \mathrm{O}_{3}$ formed on surfaces deformed prior to oxidation. On those surfaces without residual stress (as indicated by $\mathrm{X}$-ray line broadening) a complex layer of $\mathrm{CoO}, \mathrm{CoCr}_{2} \mathrm{O}_{4}$, and $\mathrm{Cr}_{2} \mathrm{O}_{3}$ formed immediately.

2. Samples having greater initial surface deformation retained the exclusive protective layer of $\mathrm{Cr}_{2} \mathrm{O}_{3}$ for longer times.

3. Water vapor in the air reduced the lifetime of the $\mathrm{Cr}_{2} \mathrm{O}_{3}$ layer drastically, that is, from a maximum 15 hours to less than $1 / 2$ hour, when sufficient surface deformation was present to allow $\mathrm{Cr}_{2} \mathrm{O}_{3}$ to form initially.

4. As the pressure of the low-water-content air is reduced, the rate of formation of $\mathrm{Cr}_{2} \mathrm{O}_{3}$ is reduced; but its lifetime as a single layer is extended.

5. The basic sequence of the formation and breakdown of the $\mathrm{Cr}_{2} \mathrm{O}_{3}$ layer on a deformed surface is as follows:

a. $\mathrm{Cr}_{2} \mathrm{O}_{3}$ is formed preferentially on a deformed surface. The oxide grows in compression.

b. The $\mathrm{Cr}_{2} \mathrm{O}_{3}$ deforms by wrinkling, causing much of the contact between oxide and metal to be lost.

c. The parts of the oxide not in contact with the metal grow thinner because of the loss of oxide through the formation of gaseous $\mathrm{CrO}_{3}$.

d. The $\mathrm{Cr}_{2} \mathrm{O}_{3}$ cracks in the thinned area, exposing a chromium-depleted alloy.

e. This alloy oxidizes rapidly mostly to CoO, pushing the rest of the $\mathrm{Cr}_{2} \mathrm{O}_{3}$ away from the metal and exposing more fresh surface.

f. The chromium-depleted surface of the alloy is oxidized; the rate slows as this zone is consumed. As a thick mixed scale forms, the diffusion path is lengthened and the rate of oxidation slows.

\section{CONCLUDING REMARKS}

The object of this investigation was to determine the mechanism of failure of the protective $\mathrm{Cr}_{2} \mathrm{O}_{3}$ layer formed on L-605 and to discover some of the factors affecting this breakdown. The failure of the chromium scale was caused by the lifting of the scale in the shape of blisters from the metal by the compressive growth stresses, followed by vaporization of the oxide. When the scale cracks at the blister tops, rapid oxidation of the chromium-depleted alloy follows the failure of $\mathrm{Cr}_{2} \mathrm{O}_{3}$ and is noted as 
a large increase in the oxidation rate. Therefore, anything that promotes $\mathrm{Cr}_{2} \mathrm{O}_{3}$ formation (i.e., silicon or prior surface deformation) will prolong the life of the protective layer. Conversely, anything that increases volatilization (i.e., water vapor) decreases the life of this layer.

There appear to be several ways of avoiding the $\mathrm{Cr}_{2} \mathrm{O}_{3}$ layer breakdown. The first is to use a higher silicon concentration to further stabilize the $\mathrm{Cr}_{2} \mathrm{O}_{3}$ layer. This, however, has the disadvantage of seriously decreasing the post-aging ductility of the alloy. Another possibility would be the use of alloying additions to act as dopants of the $\mathrm{Cr}_{2} \mathrm{O}_{3}$ scale to reduce its volatility. Changing volatility without altering the singlephase $\mathrm{Cr}_{2} \mathrm{O}_{3}$ nature of the scale or drastically increasing the rate of oxidation appears a remote possibility. An extension of this approach would be the addition of $\mathrm{Mn}$ to change the scale to $\mathrm{MnCr}_{2} \mathrm{O}_{4}$, which might be a desirable adherent scale as has been shown in the simple $\mathrm{Ni}-\mathrm{Cr}$ and $\mathrm{Co}-\mathrm{Cr}$ binary systems. One final alloying approach might be to increase the chromium content so as to mitigate depletion-zone formation. A different approach would be to polish the surface prior to oxidation. This would eliminate the $\mathrm{Cr}_{2} \mathrm{O}_{3}$ formation entirely, but the resultant scale would have a higher rate constant $K_{p}$ and would spall readily upon cooling.

Lewis Research Center,

National Aeronautics and Space Administration,

Cleveland, Ohio, February 15, 1973,

501-01.

\section{REFERENCES}

1. Wlodek, S. T.: The Oxidation of L-605 and X-40. Rep. R64FPD12, General Electric Co., Jan. 24, 1964.

2. Wolf, James S.; and Sandrock, Gary D.: Some Observations Concerning the Oxidation of the Cobalt-Base Superalloy L-605 (HS-25). NASA TN D-4715, 1968.

3. Lowell, Carl E.; and Drell, Isadore L. : Effect of Surface Preparation on Oxidation of WI-52 at $1800^{\circ}$ and $2000^{\circ} \mathrm{F}\left(1255^{\circ}\right.$ and $\left.1366^{\circ} \mathrm{K}\right)$. NASA TN D-6148, 1971.

4. Whittle, D. P.; and Wood, G. C. : Complex Scale Formation on an Iron-18\% Chromium Alloy. J. Electrochem. Soc., vol. 114, no. 10, Oct. 1967, pp. 986-993.

5. Wood, G. C. ; and Hodgkiess, T.: Characteristic Scales on Pure Nickel-Chromium Alloys at $800^{\circ}-1200^{\circ}$ C. J. Electrochem. Soc., vol. 113, no. 4, Apr. 1966, pp. 319-327. 
6. Davin, A.; Coutsouradis, D.; and Habraken, L.: Dry Corrosion of CobaltChromium Alloys at High Temperature, Influence of Ternary Additions. Cobalt, no. 35, June 1967, pp. 69-77.

7. Whittle, D. P.; Wood, G. C. ; Evans, D. J. ; and Scully, D. B.: Concentration Profiles in the Underlying Alloy During the Oxidation of Iron-Chromium Alloys. Acta Met., vol. 15, Nov. 1967, pp. 1747-1755.

8. Giggins, C. S.; and Pettit, F. S.: The Effect of Alloy Grain-Size and Surface Deformation on the Selective Oxidation of Chromium in Ni-Cr Alloys at Temperatures of $900^{\circ}$ and $1100^{\circ}$ C. Trans. AIME, vol. 245, no. 12, Dec. 1969, pp. 25092514.

9. Phalnikar, C. A. ; Evans, E. B.; and Baldwin, W. M., Jr.: High Temperature Scaling of Cobalt-Chromium Alloys. J. Electrochem. Soc., vol. 103, no. 8, Aug. 1956, pp. 429-438.

10. Kohl, Fred J.; and Stearns, Carl A.: Vaporization of Chromium Oxides from the Surface of TD-NiCr under Oxidizing Conditions. NASA TM X-52879, 1970.

11. Caplan, D.; Harvey, A.; and Cohen, M.: Oxidation of Chromium at $890^{\circ} \mathrm{C}$ to $1200^{\circ}$ C. Corrosion Sci., vol. 3, 1963, pp. 161-175. 
TABLE I. - ANALYSIS OF L-605

HEAT 8 (REF. 2)

\begin{tabular}{|l|c|}
\hline Element & Content, wt. \% \\
\hline Silicon & 0.12 \\
Manganese & 1.10 \\
Iron & 3.06 \\
Chromium & 20.06 \\
Tungsten & 14.50 \\
Carbon & .12 \\
Nickel & 10.27 \\
Cobalt & Balance \\
Sulphur & .005 \\
\hline
\end{tabular}

TABLE II. - SURFACE CONDITIONS OF L-605 PRIOR TO OXIDATION

\begin{tabular}{|l|c|c|}
\hline Surface treatment & $\begin{array}{c}\text { Roughness (rms), } \\
\mu \mathrm{m}\end{array}$ & $\begin{array}{c}\text { X-ray line breadth } \\
\text { (degrees } 2 \theta), \\
\text { corrected }\end{array}$ \\
\hline $0.5-\mu \mathrm{m}$ diamond & $5 \times 10^{-3}$ to $15 \times 10^{-3}$ & 0 \\
$600-$ Grit $\mathrm{SiC}$ & .02 to .05 & .292 \\
$400-$ Grit $\mathrm{SiC}$ & .05 to .10 & .335 \\
320 -Grit $\mathrm{SiC}$ & .08 to .12 & .410 \\
$240-$ Grit $\mathrm{SiC}$ & .12 to .17 & .535 \\
120 -Grit $\mathrm{SiC}$ & .25 to .33 & .707 \\
Ground & .02 to .15 & .626 \\
\hline
\end{tabular}




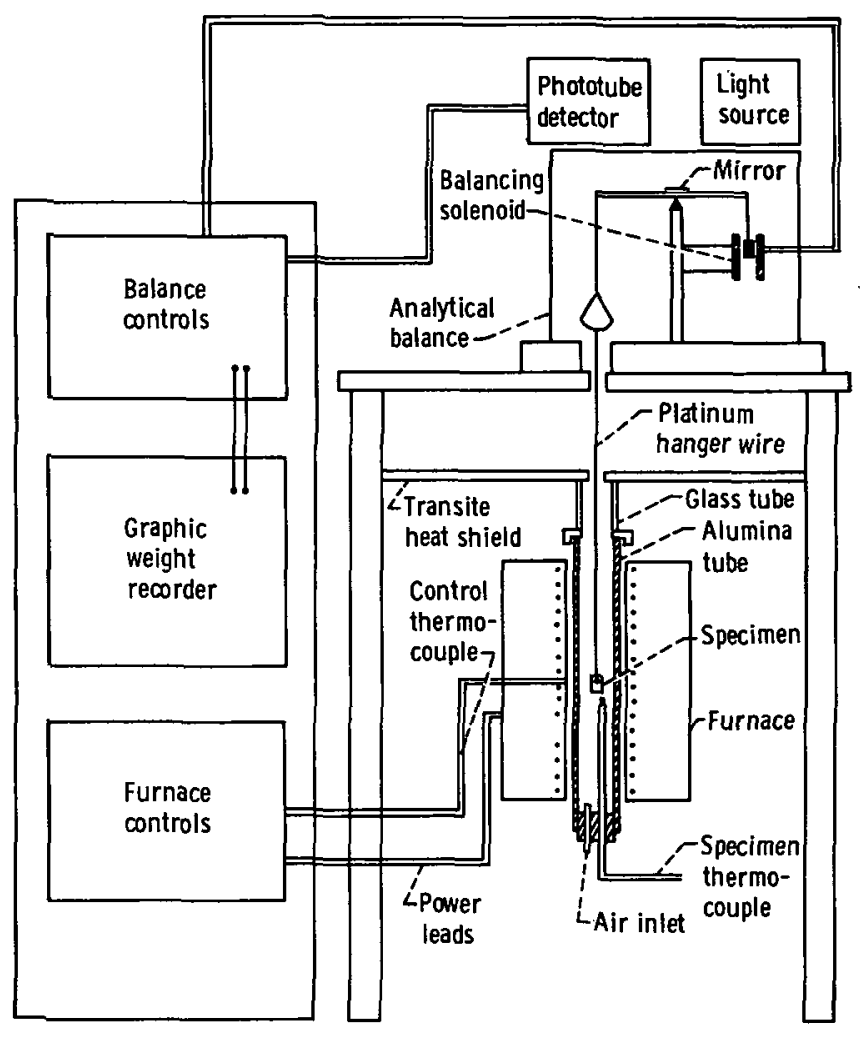

(a) Open to ambient pressure.

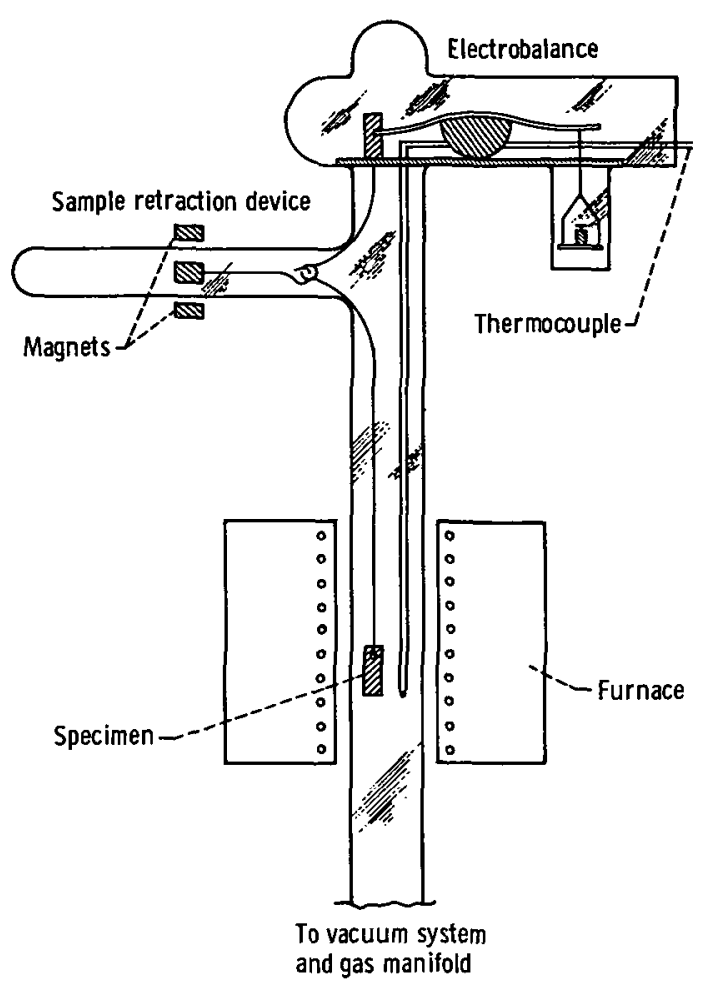

(b) With controlled atmosphere.

Figure 1. - Continuous weight gain apparatus (ref. 2).

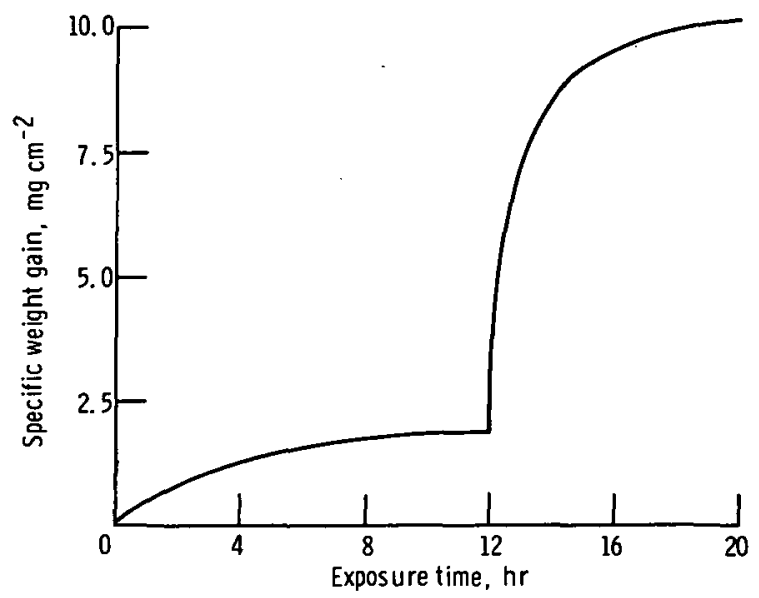

Figure 2. - Typical oxidation behavior of $L-605$ with low silicon content in air at $1100^{\circ} \mathrm{C}$. Isothermal, 700-torr air containing $2.5 \mathrm{ppm} \mathrm{H}, 0$. Sample abraded with 120 -grit SiC prior to oxidation. 


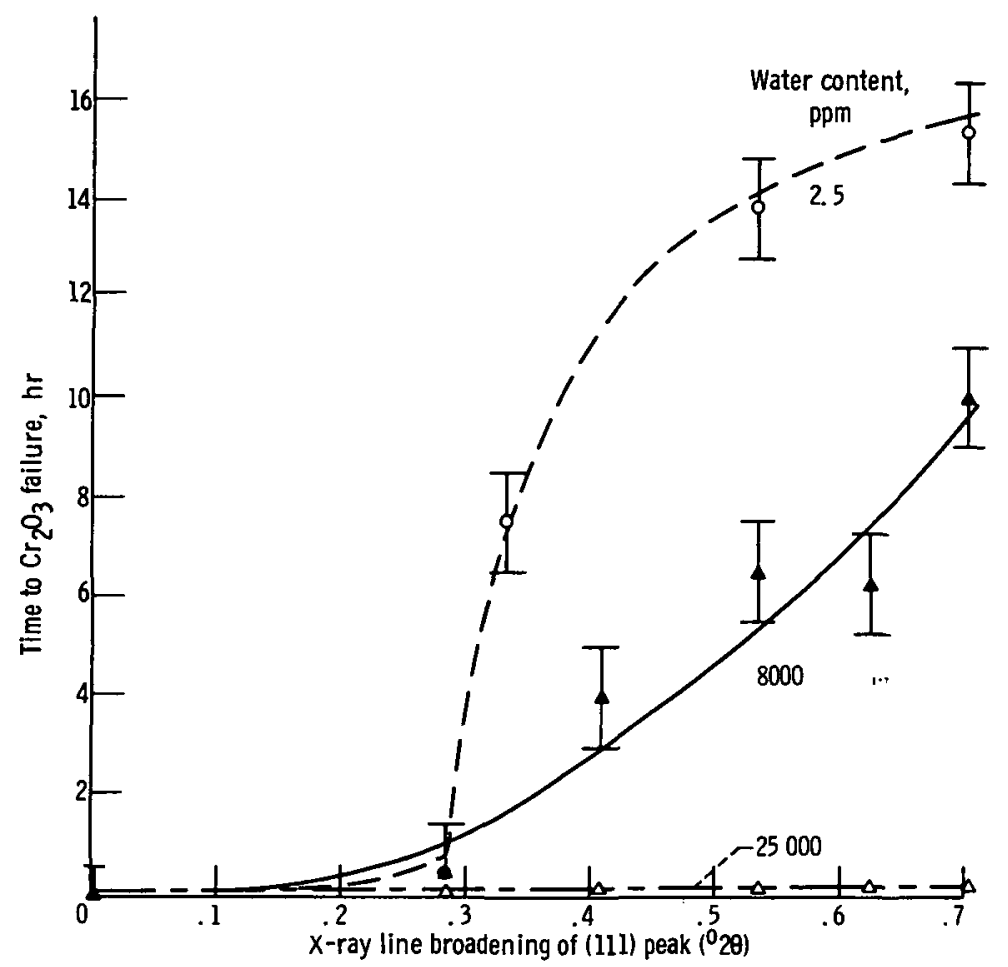

Figure 3. - Effect of water vapor and prior surface deformation as indicated by line broadening on the loss of $\mathrm{Cr}_{2} \mathrm{O}_{3}$ protection on $\mathrm{L}-605$ at $1100^{\circ} \mathrm{C}$ in still air. Ambient pressure.

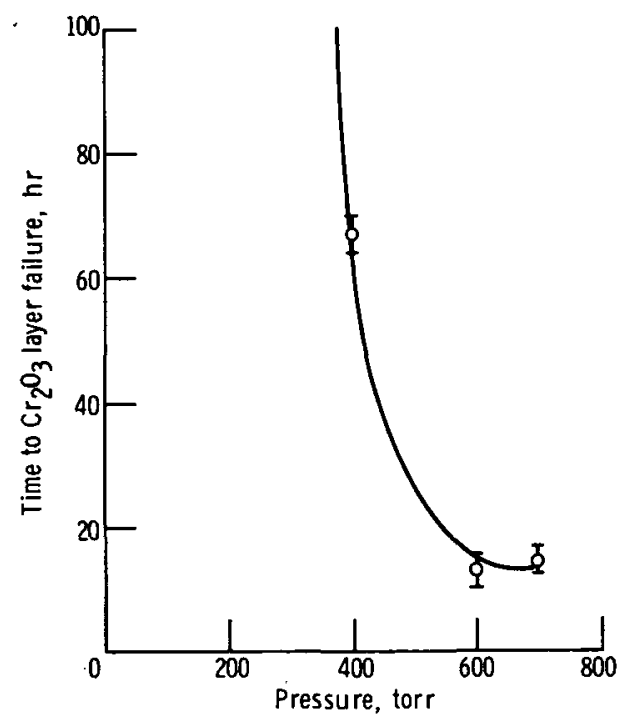

Figure 4. - Effect of pressure on breakdown of protective layer of $\mathrm{Cr}_{2} \mathrm{O}_{3}$ formed on $\mathrm{L}-605$ in air containing $2.5 \mathrm{ppm} \mathrm{H}_{2} \mathrm{O}$ at $1100^{\circ} \mathrm{C}$. 


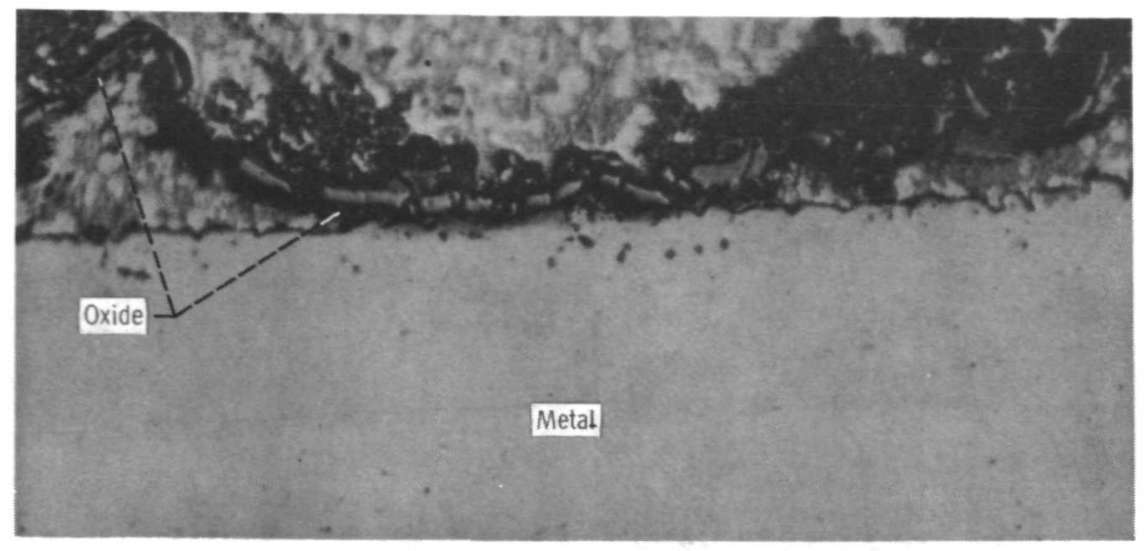

(a) Before breakdown and after 4 hours in air containing 8000 ppm $\mathrm{H}_{2} \mathrm{O}$.

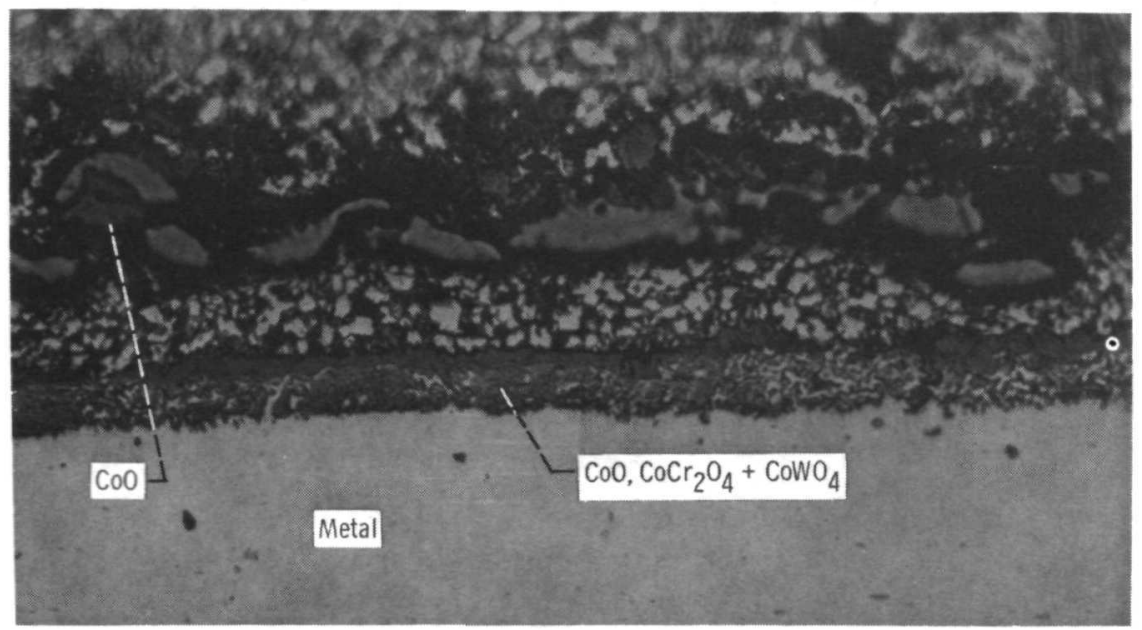

(b) During breakdown and after 6 hours in air containing $8000 \mathrm{ppm} \mathrm{H}_{2} \mathrm{O}$ followed by 10 minutes at $25000 \mathrm{ppm} \mathrm{H} \mathrm{H}_{2} \mathrm{O}$.

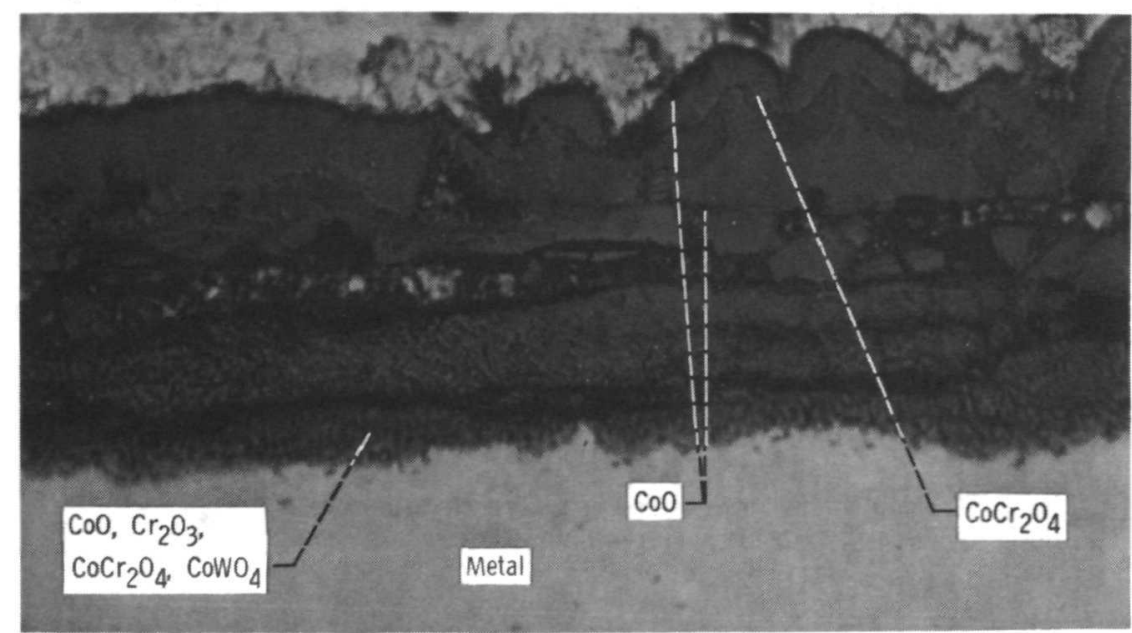

(c) After breakdown caused by 6 hours in $8000 \mathrm{ppm} \mathrm{\textrm {H } _ { 2 }} \mathrm{O}$ followed by 1 hour at $25000 \mathrm{ppm} \mathrm{\textrm {H } _ { 2 }} \mathrm{O}$.

Figure 5. - Microstructure of scales on $\mathrm{L}-605$ oxidized at $1100^{\circ} \mathrm{C}$ in air before, during, and after breakdown of $\mathrm{Cr}_{2} \mathrm{O}_{3}$ layer by saturating the air with $\mathrm{H}_{2} \mathrm{O}$ vapor for 6 hours after start of test. Unetched, X250. 


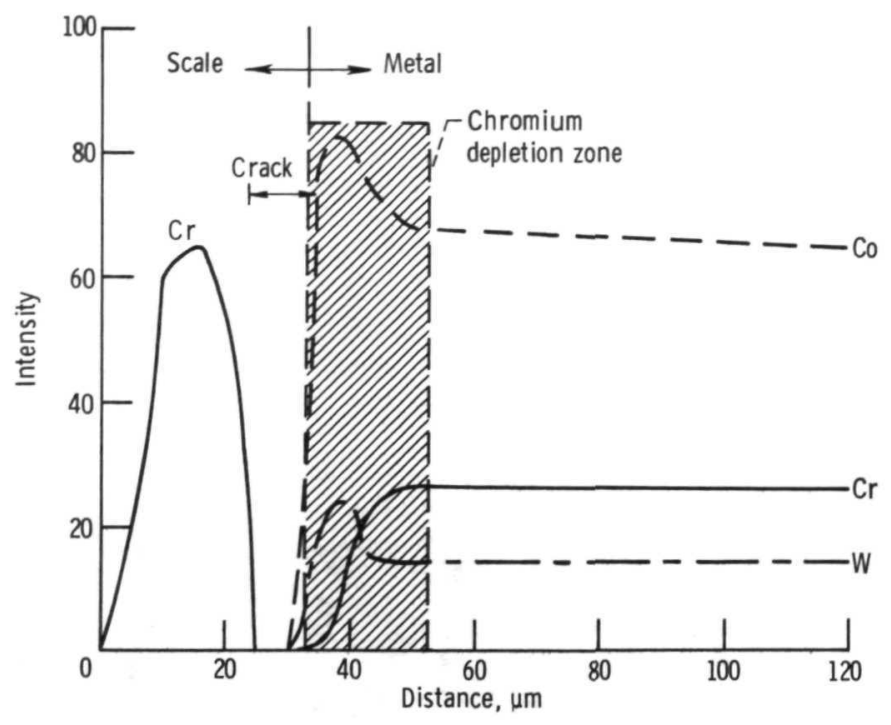

Figure 6. - Microprobe traces on $\mathrm{L}-605$ before breakdown of $\mathrm{Cr}_{2} \mathrm{O}_{3}$ scale and after 4 hours at $1100^{\circ} \mathrm{C}$ in air containing $8000 \mathrm{ppm} \mathrm{H} 2 \mathrm{O}$. Note depletion of $\mathrm{Cr}$ in metal at scale-metal interface.

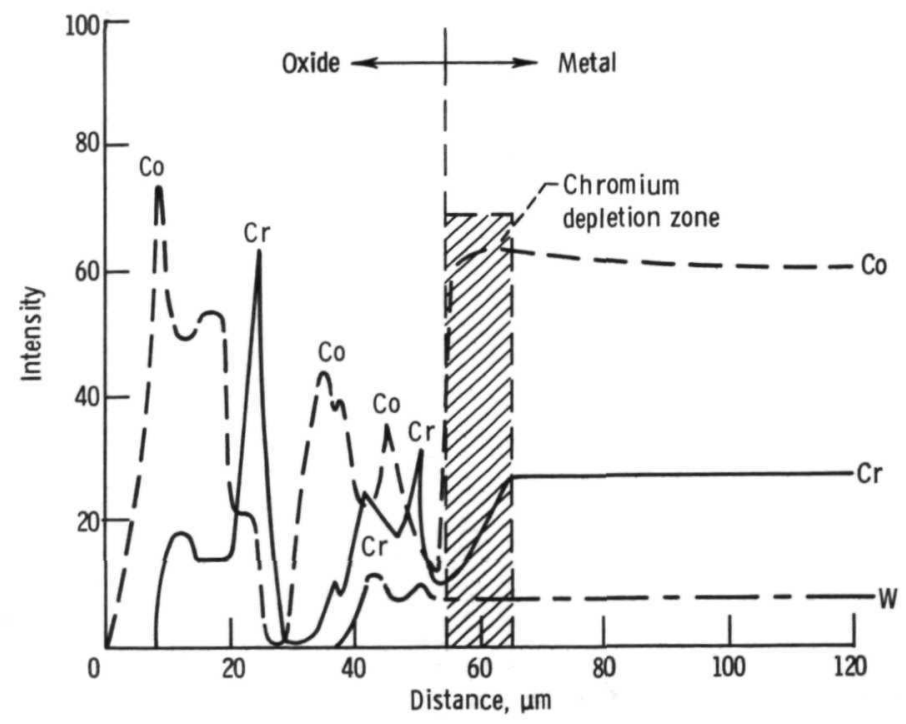

Figure 7. - Microprobe traces on $\mathrm{L}-605$ during breakdown of $\mathrm{Cr}_{2} \mathrm{O}_{3}$ scale and after 6 hours in air containing 8000 ppm $\mathrm{H}_{2} \mathrm{O}$ followed by 10 minutes at $25000 \mathrm{ppm} \mathrm{H}_{2} \mathrm{O}$. 


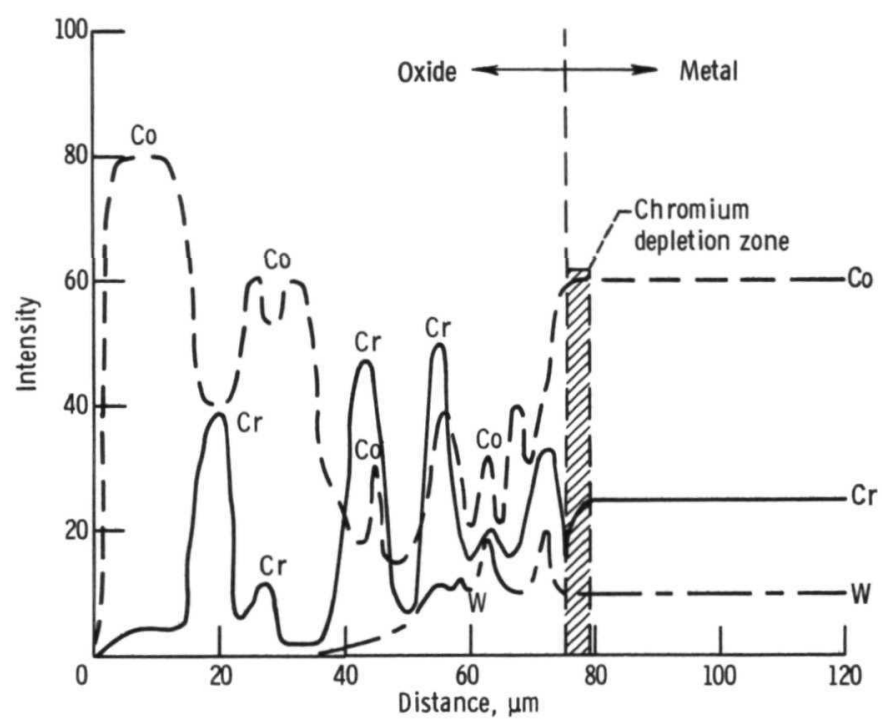

Figure 8. - Microprobe traces on $\mathrm{L}-605$ after breakdown of $\mathrm{Cr}_{2} \mathrm{O}_{3}$ scale caused by 6 hours at $1100^{\circ} \mathrm{C}$ in air containing $8000 \mathrm{ppm} \mathrm{H}_{2} \mathrm{O}$ followed by 1 hour at $25000 \mathrm{ppm} \mathrm{H}_{2} \mathrm{O}$. 


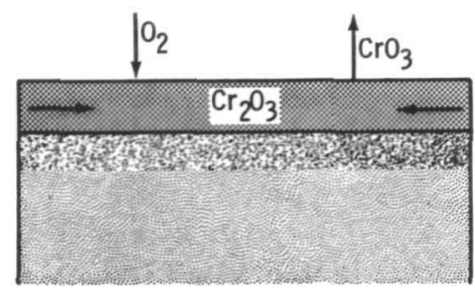

(a) First scale growth.

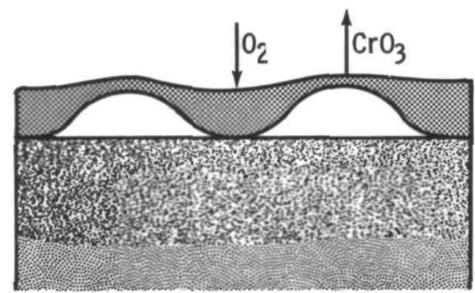

(c) Local thinning of scale.

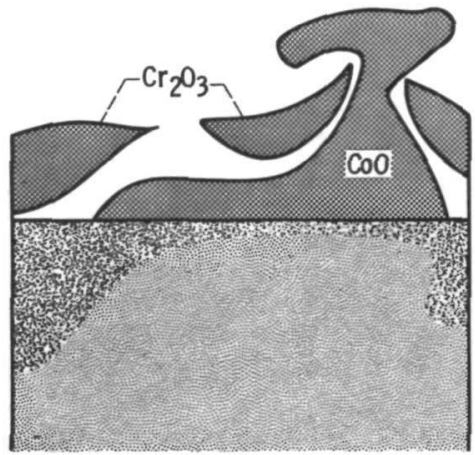

(e) During breakdown.

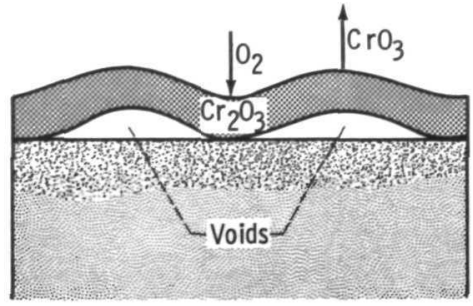

(b) Wrinkling of scale.

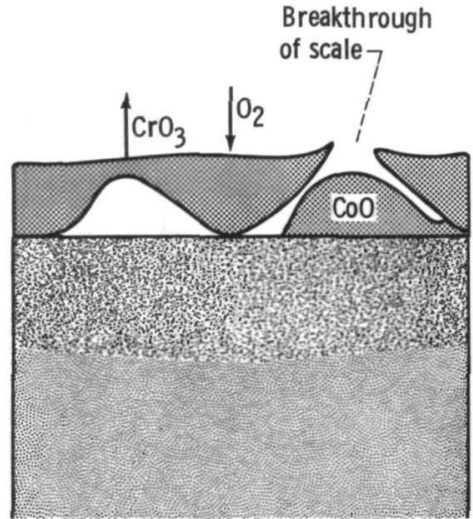

(d) At beginning of breakdown.

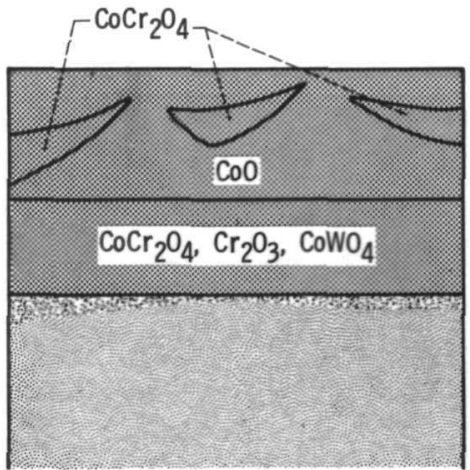

(f) After breakdown.

Figure 9. - Proposed model for formation and breakdown of protective oxide layer on $\mathrm{L}-605$ during oxidation at $1100^{\circ} \mathrm{C}$. 
"The aeronautical and space activities of the United States shall be conducted so as to contribute . . . to the expansion of buman knowledge of phenomena in the atmosphere and space. The Administration shall provide for the widest practicable and appropriate dissemination of information concerning its activities and the results thereof."

- National Aeronautics and SPace ACt of 1958

\section{NASA SCIENTIFIC AND TECHNICAL PUBLICATIONS}

TECHNICAL REPORTS: Scientific and technical information considered important, complete, and a lasting contribution to existing knowledge.

TECHNICAL NOTES: Information less broad in scope but nevertheless of importance as a contribution to existing knowledge.

\section{TECHNICAL MEMORANDUMS:}

Information receiving limited distribution because of preliminary data, security classification, or other reasons. Also includes conference proceedings with either limited or unlimited distribution.

CONTRACTOR REPORTS: Scientific and technical information generated under a NASA contract or grant and considered an important contribution to existing knowledge.
TECHNICAL TRANSLATIONS: Information published in a foreign language considered to merit NASA distribution in English.

SPECIAL PUBLICATIONS: Information derived from or of value to NASA activities. Publications include final reports of major projects, monographs, data compilations, handbooks, sourcebooks, and special bibliographies.

\section{TECHNOLOGY UTILIZATION}

PUBLICATIONS: Information on technology used by NASA that may be of particular interest in commercial and other non-aerospace applications. Publications include Tech Briefs, Technology Utilization Reports and Technology Surveys.

Defails on the availability of these publications may be obtained from:

SCIENTIFIC AND TECHNICAL INFORMATION OFFICE 